\title{
Diagnosing tumours on routine surgical sections by immunohistochemistry: use of cytokeratin, common leucocyte, and other markers
}

\author{
RN POSTON, YS SIDHU \\ From the Department of Histopathology, United Medical and Dental Schools, Guys Hospital, London
}

SUMMARY Tumours of uncertain tissue of origin were investigated by immunohistochemistry on formalin fixed paraffin embedded sections. Two antibodies-PD7/26, an anti common leucocyte antigen, and CAM5.2, an anticytokeratin-recognised most lymphomas and carcinomas, respectively: $88 \%$ of these tumours were identified by the two antibodies alone. These antibodies permitted the separation of the cases into groups: positive with CAM5.2, positive with PD7/26, and a third comprising those negative with both. The negative group contained other tumours and a small number of carcinomas and lymphomas; many of the lymphomas were, apparently, of histiocytic origin.

Comparison of CAM5.2 with other epithelial markers showed that it was the most effective. Some further classification of the tumours was carried out with a panel of organ and cell specific antibodies: mesotheliomas were recognised by their pattern of reactivity with epithelial markers. Overall, the tumour type was determined in $90 \%$ of cases. Immunohistochemistry performed as described can be a potent aid to the diagnostic histopathology of tumours.

Previous reports by Gatter $e t a^{12}$ and by Lauder $e t$ $a l^{3}$ have shown that tumours causing diagnostic difficulty by conventional histology can have their tissue of origin determined by immunohistochemistry on sections from formalin fixed paraffin embedded material. Recognition of the tissue of origin permits the tumours to be divided into carcinomas, lymphomas, sarcomas, and other less common types of tumour. Using a combination of the common leucocyte antigen and epithelial specific monoclonal antibodies, Gatter et al classified most anaplastic tumours as either lymphomas or carcinomas, mostly as lymphomas. Earlier studies had been hampered by the lack of epithelial markers capable of identifying most carcinomas: those used had limited or poorly defined spectra of reactivities. We, like Gatter et al, ${ }^{2}$ have taken advantage of the recent production of a highly effective epithelial marker, CAM5.2, by Makin et $a l^{4}$ and have performed a similar study on routine surgical material. CAM5.2 reacts with cytokeratins, the intermediate filament proteins of normal epithelial cells, and carcinomas. Tumour cells generally produce the intermediate filament proteins characteristic of their tissue of origin, although minor differences

Accepted for publication 19 December 1985 may be found, and these proteins are proving to be useful markers in the identification of many tumours. ${ }^{5}$ At the same time we compared CAM5.2 and several other epithelial markers.

CAM5.2 is a good marker for carcinoma cells in paraffin sections: in the original study ${ }^{4}$ all of a group of 96 carcinomas, derived from many organs, were positively stained. CAM5.2 reacts against low molecular weight cytokeratins of types 8, 18, and 19 (EB Lane, personal communication) as classified by Moll et al. ${ }^{6}$ These are present in almost all normal epithelia with the exception of stratified squamous epithelium. Nevertheless, squamous cell carcinomas were found to react.

Another monoclonal antibody to cytokeratins, LP34, was also assessed. This reacts against higher $\stackrel{\circ}{N}$ molecular weight cytokeratins that are well expressed $\omega$ in stratified squamous epithelia (EB Lane, personal communication) and also with type 18, which is $\stackrel{0}{=}$ present in many other types of epithelial cell. The epithelial cell reactive monoclonal HMFG2 was also tested. This was raised against the milk fat globule $\frac{T}{7}$ antigen and mammary epithelial cells. ${ }^{89}$

Previous studies have shown that PD7/26 is a $\frac{\odot}{\Phi}$ highly effective marker for the recognition of lym- $\stackrel{\square}{\square}$ phoid cells in paraffin sections, whether benign or ma- 
lignant. ${ }^{10}$ It reacts strongly with lymphocytes and is positive, but to a lesser degree, with macrophages and other lymphoid cells.

With most of the tumours further typing with a panel of antibodies was performed, once they had been provisionally classified as carcinoma, lymphoma, or other type, by the initial use of the CAM5.2 and PD7/26 antibodies.

\section{Methods}

Routine surgical sections fixed in formol saline and embedded in paraffin were referred by the clinical histopathologists of Guys, Lewisham, and New Cross hospitals from cases in which diagnostic difficulty had remained after conventional histology. The cases were divided according to the problem they presented: tumours of uncertain tissue of origin, mainly anaplastic $(n=88)$-these are referred to as the anaplastic tumours; carcinoma of uncertain organ of origin (including distinction of mesothelioma from carcinoma) $(n=53)$; lymphoma of uncertain cell type $(n=31)$; benign or malignant lesion $(n=13$, excluding lymphadenopathy).

This account is primarily concerned with the anaTable 1 Antibody panel plastic tumours, but some of the results presented are derived from cases of the other groups. In addition, frozen blocks were received in a small number of cases, mostly lymphomas.

Immunohistochemistry with monoclonal antibodies was performed by the indirect immunoperoxidase technique using phosphate buffered saline (FA buffer, Difco Laboratories) as the diluent: a detailed method sheet is available on request. Initially all markers were assessed by titration on normal tissues and tumours of known type. Enzyme treatment of the sections was found to be essential for effective staining with most antibodies, and the optimal enzyme and conditions used varied from one antibody to another. ${ }^{11}$ Incubation with monoclonal antibodies was carried out for 90 minutes at room temperature. Table 1 shows the antibodies used, their dilutions, and digest conditions. For polyclonal antibodies a PAP technique was used; and incubation with the primary antibody was carried out for 30 minutes. With weakly reactive antisera, such as vimentin and calcitonin, this was extended to three hours. In the subsequent stages normal human serum was added to the conjugate at a dilution of $1 / 40$ for the blocking of unwanted reactions, and improved reproducibility

\begin{tabular}{|c|c|c|c|c|}
\hline Monoclonal antibody & Specificity & Enzyme and time & Working dilution & Source or reference \\
\hline $\begin{array}{l}\text { PD7/26 } \\
\text { TAL } 1 B 5 \\
\text { TO5/29 } \\
\text { CAM5.2 } \\
\text { LP34 } \\
\text { HMFG2 } \\
\text { ID4/DZ }\end{array}$ & $\begin{array}{l}\text { Leucocyte common antigen } \\
\text { HLA-DR } \\
\text { C3b receptor } \\
\text { Cytokeratins (see text) } \\
\text { Cytokeratins (see text) } \\
\text { Milk fat globule antigen } \\
\text { Thyroglobulin }\end{array}$ & $\begin{array}{l}\text { Trypsin } 5^{\prime} \\
\text { Pronase } 5^{\prime} \\
\text { Pronase 5' } \\
\text { Trypsin } 30^{\prime} \\
\text { Trypsin } 10^{\prime} \\
\text { Trypsin } 10^{\prime} \\
\text { Trypsin } 10^{\prime}\end{array}$ & $\begin{array}{l}20 \\
40 \\
20 \\
20 \\
20 \\
20 \\
40\end{array}$ & $\begin{array}{l}10 \\
7 \\
12 \\
4 \\
\text { ICRF } \\
9 \\
\text { Dr Shepherd, Guys } \\
\text { Hospital }^{24}\end{array}$ \\
\hline 946.11 & $\alpha$-fetoprotein & None & 100 & Unipath \\
\hline
\end{tabular}

Polyclonal antibodies

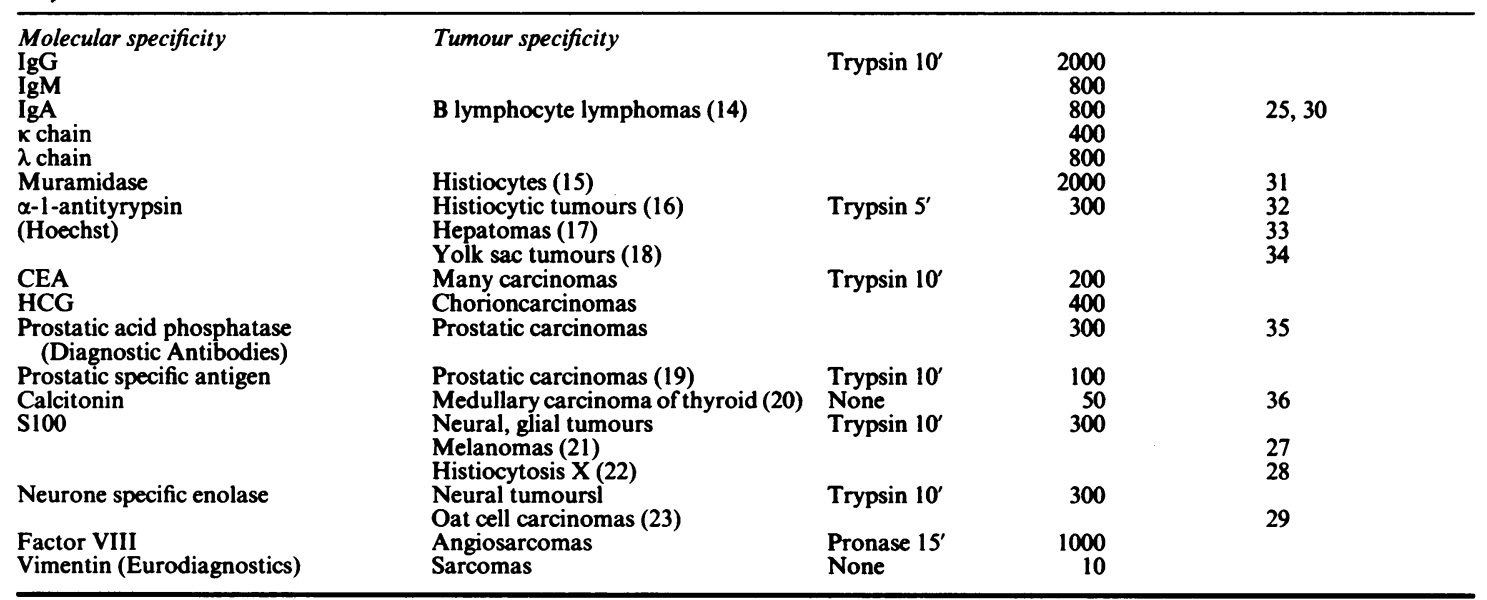

All monoclonal antibodies are culture supernatants. All polyclonal antibodies were supplied by Dako, except where indicated.

CEA = Carcinoembryonic antigen; $\mathbf{H C G}=$ human chorionic gonadotrophin. 
was achieved by monitoring the length of the diaminobenzidine reaction by eye, which normally was about five minutes. The sections were then counterstained lightly with haematoxylin.

All tumours of uncertain tissue of origin were tested with CAM5.2 and PD7/26 and either simultaneously or subsequently with other appropriate antibodies of the panel available (Table 1). In a small number of cases PD7/26 was used mixed with another common leucocyte monoclonal 2B11. ${ }^{10}$ This procedure might have possible advantages as $2 \mathrm{~B} 11$ reacts more strongly with $\mathrm{T}$ lymphocytes. The epitope recognised, however, was more labile to fixation, and this antibody was not considered to add sufficient additional information to justify routine use.

Staining was graded semiquantitatively on a scale of + to +++ , corresponding to weak, moderate, and strong reactions. Traces of staining were also noted but classed as negative. Negative controls were provided by irrelevant antibodies of the same species as the test antibody and were done with each case. Positive control sections for all antibodies were included with each batch of sections stained.

Results were stored and analysed using a computer program written specifically for the purpose on a Sinclair Spectrum computer (it can hold 180 patient records in memory at a time), which incorporated a modification of the Tasword 2 word processing program (Tasman Software). This facilitated the generation of clinical reports from the data by the automatic insertion of patient details and marker results into the text file of the word processor in the required report format. Full details of this system will be published in a further paper.

\section{Results}

The common leucocyte monoclonal PD7/26 and the cytokeratin monoclonal CAM 5.2 were an exceedingly useful combination of antibodies, enabling the anaplastic tumours to be divided into three categories: PD7/26 positive, CAM5.2 positive, and those negative with both markers. The specificity of these markers ${ }^{410}$ allowed the first group to be diagnosed as lymphomas and the second as either carcinomas or mesotheliomas. Thymomas and teratomas also all contained CAM5.2 positive cells, but were distinguished by histological features. The third group contained assorted tumour types that required further analysis with a panel of antibodies. For all these analyses to be performed correctly the malignant cell population had to be identified and distinguished from other normal or reactive cells present in the tissues.

By applying the marker panel to the tumours of unknown tissue of origin, a definite diagnosis of origin was made in $90 \%$ of cases. Forty two per cent
Table 2a Tumours of unknown type (88 cases) with immunohistochemical markers (figures in parentheses are numbers \%)

\begin{tabular}{lll}
\hline Diagnosis & $\begin{array}{l}\text { Provisional } \\
\text { without markers }\end{array}$ & $\begin{array}{l}\text { With } \\
\text { immunohistochemistry } \\
\text { markers }\end{array}$ \\
\hline Carcinoma & $24(27)$ & $36(41)$ \\
Lymphoma & $26(30)$ & $26(30)$ \\
Sarcoma & $12(14)$ & $10(11)$ \\
Other & $7(8)$ & $7(8)$ \\
No preference & $19(22)$ & $9(10)$ \\
No positive results & &
\end{tabular}

Table $2 \mathrm{~b}$ Comparison of histological immunohistochemical diagnoses (88 tumours of unknown type, diagnosis of tissue of origin)

\begin{tabular}{lllr}
\hline Concord & $50(57 \%)$ & $\begin{array}{l}\text { No histological diagnosis } \\
\text { Do immunohistochemical } \\
\text { diagnosis }\end{array}$ & $\begin{array}{r}19(22 \%) \\
9(10 \%)\end{array}$ \\
\hline
\end{tabular}

Table 2c Comparison of epithelial markers

\begin{tabular}{llll}
\hline Carcinomas & \multicolumn{3}{c}{ Percentage total } \\
\hline CAM5.2 & $+51 / 57$ & 89 & \\
HMFG2 & $+39 / 59$ & 66 & $(8 / 8$ breast positive $)$ \\
LP34 & $+13 / 24$ & 54 & \\
CEA & $+16 / 30$ & 57 & \\
Mesotheliomas & & & \\
CAM5.2 & $+8 / 8$ & 100 & \\
HMFG2 & $+3 / 7$ & 43 & \\
LP34 & $+8 / 8$ & 100 \\
CEA & $+0 / 8$ & 0 \\
\hline
\end{tabular}

were diagnosed as carcinomas, $30 \%$ as lymphomas, and $19 \%$ as other tumours. Table $2 \mathrm{a}$ details the comparison of these figures and those based on histological diagnosis alone. Of those finally diagnosed as carcinomas, $87 \%$ were positive with CAM5.2, and $88 \%$ of the lymphomas were PD7/26 positive. Thus the diagnosis of carcinoma or lymphoma was only occasionally unsuccessful with the combined use of CAM5.2 and PD7/26 alone, and in no instance was there any evidence of double staining or any other inconsistent result with these markers. In total, $60 \%$ of this tumour group were diagnosed as carcinoma or lymphoma by the use of these two antibodies alone. After the use of all the markers there remained only nine of the 88 anaplastic tumours in which the origin could not be determined, and in five of these the histological material was unsatisfactory. One lesion was reclassified as non-malignant as a result of the immunohistochemistry.

The classification of tumours was as successful as with other groups: positive results were obtained in 18 of $19(95 \%)$.

CARCINOMAS AND OTHER CAM5.2 POSITIVE TUMOURS

To obtain the optimal results with CAM5.2 pro- 


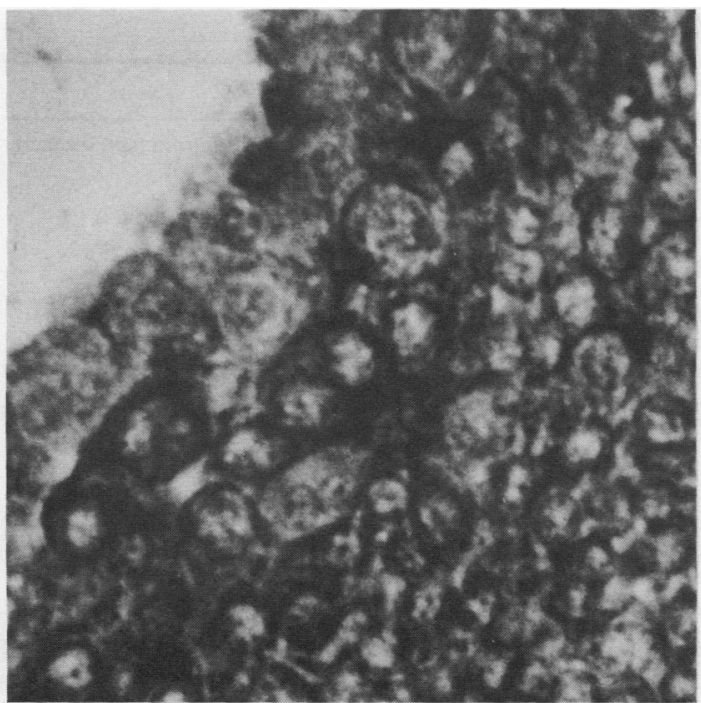

Fig. 1 Carcinoid stained with CAM5.2. All tumour cells are strongly reactive. Section treated with trypsin for $30^{1}$. without enzyme treatment the reaction was very weak.

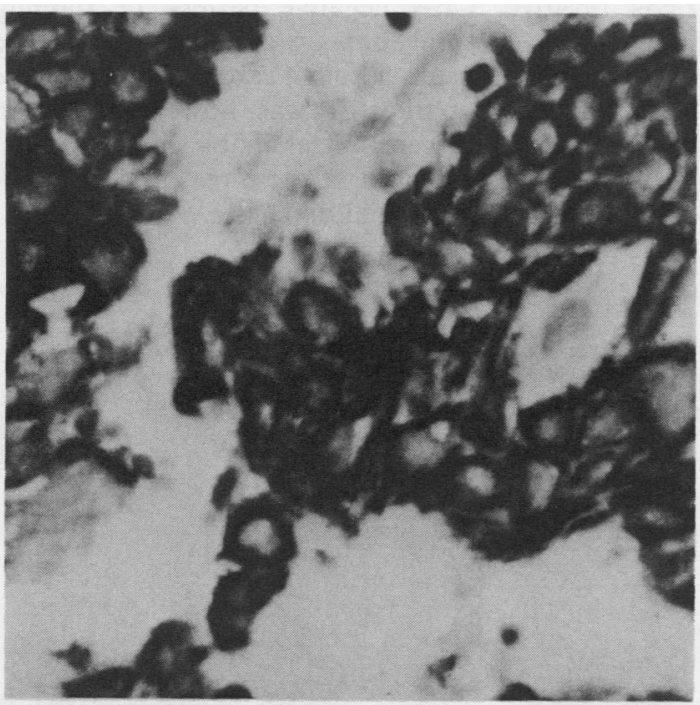

Fig. 2 Squamous cell carcinoma of vagina stained with LP34. Many areas of cells are strongly reactive.

longed digestion with trypsin or pepsin was necessary. Then most positive tumours gave strong uniform staining (Fig. 1). A small number of anaplastic tumours gave weaker reactions: this was particularly noticeable in lung tumours, with both large and small (oat) cell carcinomas giving only small areas of strong cytoplasmic staining on a minority of cells. Careful microscopy with a high power objective was required to identify this type of staining. Nevertheless, there

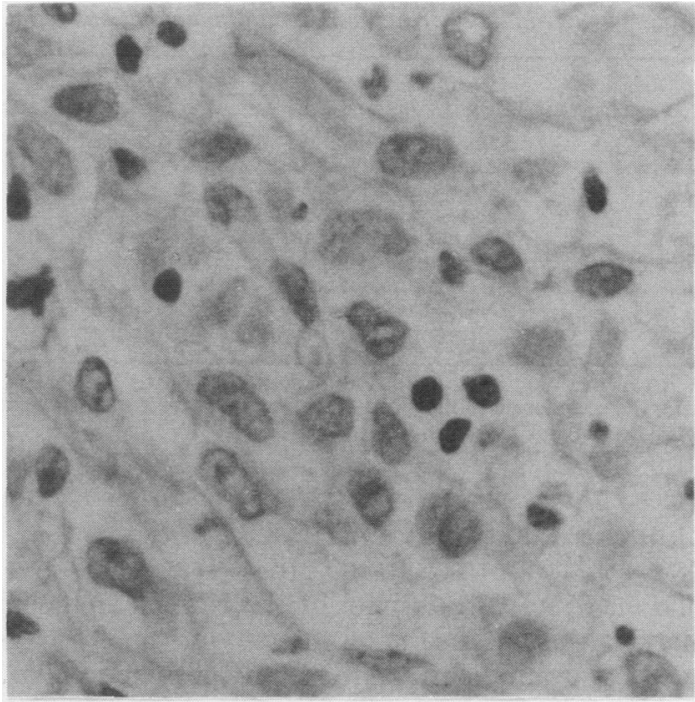

Fig. 3 Squamous cell carcinoma of vagina, (same case as that in Fig. 2) showing only a trace staining with CAM5.2.

were two probable oat cell carcinomas that failed to react with all the markers tested.

Some squamous carcinomas also gave weak staining of only a proportion of the cells, usually with a more diffuse staining of the cytoplasm. One of these tumours gave only a trace reaction with CAM5.2 but stained strongly with LP34 (Figs. 2 and 3; case 5, Table 3).

Corroborative evidence for the diagnosis of thymoma was obtained in two of five suspected cases by showing the presence of an intimate mixture of CAM5.2 and PD7/26 cells in the lesion: the lymphoid cells were shown to be pure populations of thymocytes (or $\mathrm{T}$ lymphocytes) by the staining of parallel frozen sections for surface markers.

Discrimination between benign and malignant lesions was also aided by the use of the CAM5.2 antibody. In 13 patients presenting with this problem the presence of positive abnormal cells in four allowed carcinoma to be diagnosed, while the absence of these cells in another three helped to confirm that the condition was benign.

\section{CAM5. 2 NEGATIVE TUMOURS REACTIVE WITH} OTHER EPITHELIAL MARKERS

Only six tumours were found that were CAM5.2 negative but positive with other epithelial markers (Table 3). These included two carcinomas that were HMFG2 positive. A seminoma of the testis was CAM5.2 negative, a result that correlates with the negativity of normal testis, ${ }^{4}$ but was carcinoembryonic antigen (CEA) positive. An undifferentiated liver tumour gave the same pattern. 
Table 3 CAM5.2 negative tumours in which other epithelial markers were detected

\begin{tabular}{|c|c|c|c|}
\hline Age and sex & Site and histology & Markers positive & Final diagnosis \\
\hline $\begin{array}{l}70 \mathrm{~F} \\
? \stackrel{\mathrm{F}}{40 \mathrm{M}} \\
22 \mathrm{~F}\end{array}$ & $\begin{array}{l}\text { Spindle/giant cell tumour in thyroid } \\
\text { Anaplastic tumour breast (necropsy specimen) } \\
\text { Seminoma testis } \\
\text { Undifferentiated tumour in liver, } \\
\text { ? histiocytic lymphoma }\end{array}$ & $\begin{array}{l}\text { HMFG2 (PD7/26 negative) } \\
\text { HMFG2 (PD7/26 negative) } \\
\text { CEA } \\
\text { vimentin, CEA* }\end{array}$ & $\begin{array}{l}\text { Carcinoma of thyroid (spindle cell) } \\
\text { Carcinoma of breast } \\
\text { Seminoma } \\
\text { Sarcoma (Ewings tumour?) }\end{array}$ \\
\hline $87 \mathrm{~F}$ & $\begin{array}{l}\text { Carcinoma of vagina/cervix, previous } \\
\text { carcinoma of colon }\end{array}$ & LP34 & Squamous cell carcinoma \\
\hline $66 \mathrm{M}$ & $\begin{array}{l}\text { Anaplastic tumour in vertebral bone } \\
\text { (decalcified in formic acid) }\end{array}$ & $\begin{array}{l}\text { Prostatic acid phosphatase } \\
\text { (specific antigen negative) }\end{array}$ & Carcinoma of prostate \\
\hline
\end{tabular}

*CEA probably present in reactive macrophages only.

After the completion of the main study a further breast tumour was found that was HMFG2 positive and CAM5.2 negative. The pattern was consistent over three biopsies.

CARCINOMAS: OTHER EPITHELIAL MARKERS, AND FURTHER CLASSIFICATION

The incidence of positivity of the various epithelial markers was assessed in all the tumours finally diagnosed as carcinomas. CAM5.2 was positive in $89 \%$, making it by far the most efficient marker (Table $2 \mathrm{c}$ ).

A total of $\mathbf{4 2}$ tumours of metastatic or anaplastic carcinomas were referred for the determination of the organ of origin. With the antibodies available definitive information could only be given for 10 prostatic carcinomas and two thyroid carcinomas ( $26 \%$ of the total) on the basis of their reaction with the prostate specific markers thyroglobulin and calcitonin, respectively. Thyroglobulin may, however, have been an ineffective marker for thyroid carcinomas as seven other carcinomas in the gland were negative.

Carcinoids (four cases) were distinguished by the combination of positive neurone specific enolase and CAM5.2 staining.

The polyclonal anti- $\alpha$-fetoprotein antiserum used initially was ineffective at staining hepatomas, although cells in gonadal tumours showing yolk sac differentiation stained strongly. A monoclonal antibody (Unipath) obtained subsequently gave strong granular cytoplasmic staining of hepatomas.

Using various markers, some useful information was derived in a further $17(40 \%)$ of the carcinomas of unknown organ of origin, including negative results (such as prostate), where these were relevant. Thus overall, immunohistochemistry contributed to the determination of the origin of two thirds of these carcinomas.

\section{MESOTHELIOMAS}

Twelve tumours were referred for discrimination between mesothelioma and carcinoma. All reacted positively with CAM5.2. A negative reaction for CEA is a recognised feature of mesotheliomas, ${ }^{13}$ and in nine CEA staining was negative. This negativity occurred despite the presence of non-specific antibodies in the antiserum which can give false positive reactions, and, ideally, should be absorbed out. ${ }^{14}$

A final diagnosis of mesothelioma based on a combination of histology and markers combined was $\vec{A}$ made in eight, and in all but one the staining with LP34 was strong $(+++)$ (Fig. 4). Likewise, CAM5.2 gave strong staining in all cases. HMFG2 reactions in the mesotheliomas were highly variable, ranging from negative to strongly positive. The CAM5.2 positive, LP34 positive, CEA negative pattern of staining found in the mesotheliomas was apparently specific for them, as it was absent in 14 carcinomas that were tested with these markers. It was, however, found in two tumours that were unclassifiable histologically, but interestingly, in both of these mesothelioma entered into their differential diagnosis.

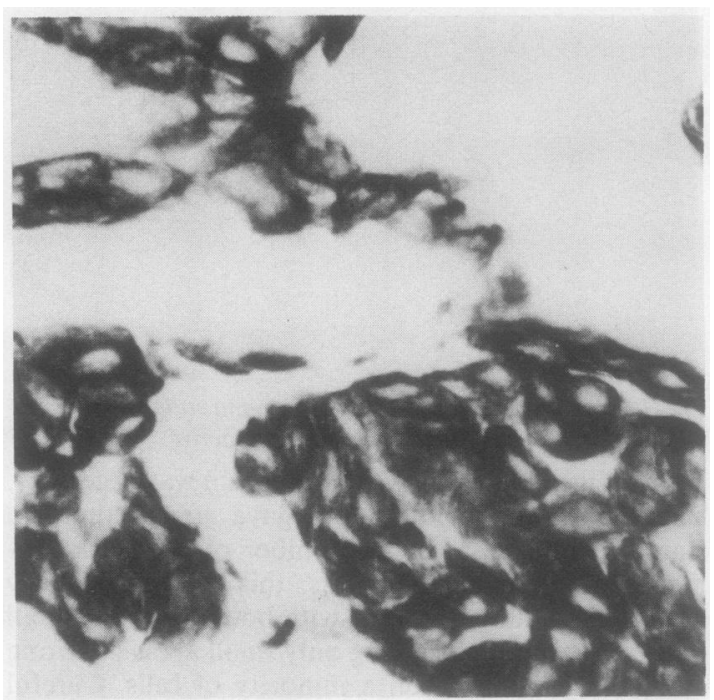

Fig. 4 Mesothelioma: epithelial component is stained strongly with LP34. 


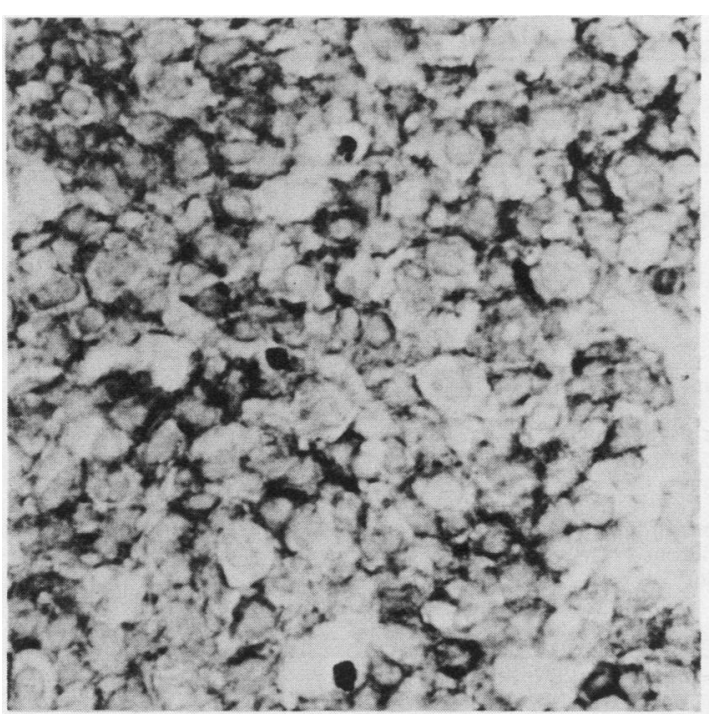

Fig. 5 Large celled lymphoma of skin stained with PD7/26. Many tumour cells show moderate staining.

\section{LYMPHOMAS: PD7/26 POSITIVE TUMOURS}

Apart from the 26 tumours of the anaplastic group that were diagnosed as lymphoma, paraffin sections of another 31 cases of known non-Hodgkin's lymphoma were received for further typing. Both of these groups, except the five cases described below, were positive with PD7/26 (Fig. 5). The strength of staining varied from case to case, with large cell tumours more commonly giving the weaker reactions. The staining was uniform from cell to cell, except when the tumours contained mixed cell populations-as seen for instance, in follicle centre cell lymphomas.

Detailed characterisation of the cell type of the lymphomas was attempted using the other antibodies of the panel (Table 1). Only cytoplasmic immunoglobulins were detectable, except for occasional traces of surface IgM. HLA-DR staining intensity varied inversely with the length of fixation, ${ }^{11}$ and macrophages were the only cell type that reacted well. It was therefore of limited value. C $3 b$ receptor staining of follicular dendritic cells behaved similarly in relation to fixation; too few follicular lymphomas were seen to assess its value in their diagnosis.

In nine $(27 \%)$ of the 33 cases fully investigated monoclonal expression of immunoglobulin was shown by staining with one light chain only, indicating a B lymphocyte origin. In five (15\%) IgM heavy chain was expressed, but no light chain staining was obtained; these lesions were also probable B lymphocyte lymphomas. These results, combined with the eight histiocytic lymphomas detected (see below), allowed an indication of cell type to be given in 22 of
$33(67 \%)$ of cases. A comparison can be made with similar investigations that were carried out on lymphomas in frozen sections, in which 10 of $14(69 \%)$ were shown to be monoclonal B cell lesions and one histiocytic tumour was found.

\section{LYMPHOMAS: PD7/26 NEGATIVE AND}

HISTIOCYTIC TUMOURS

Two tumours gave a negative result, and three more showed only a trace of staining with PD7/26 and yet were diagnosed by immunohistochemistry as lymphomas (Table 4). Histologically, four of the five were thought to be lymphomas and the other was of uncertain type. In all but the uncertain type, the tumour cells stained for either alpha-1-antitrypsin or muramidase and were therefore considered to be of histiocytic origin (Fig. 6). Two further lymphomas contained malignant cells reacting with histiocytic markers but were positive with PD7/26.

Several tumours, which histologically were not lymphomas, also reacted with histiocytic markers. Three of these were, however, PD7/26 positive and had been provisionally diagnosed histologically as malignant fibrous histiocytomas, being tumours of soft tissues, liver, and bone, respectively (Table 4). A tumour that had most probably arisen as a giant cell tumour of bone contained a pleomorphic population of cells, many of which reacted with macrophage markers. This result supports the diagnosis of origin, as Burmester et al $^{16}$ showed that these tumours react with macrophage markers.

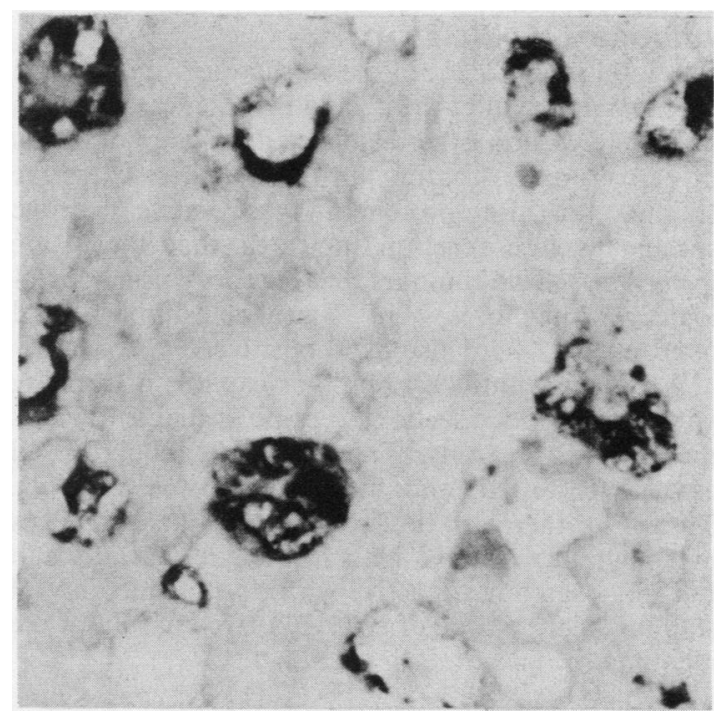

Fig. 6 Probable histiocytic lymphoma infiltrating brachial plexus stained with $\alpha$-1-antitrypsin antibody. Large cells are strongly stained (case 4, Table 4). 
Table 4 PD7/26 negative lymphomas and histiocytic tumours

\begin{tabular}{|c|c|c|c|c|c|c|}
\hline \multirow{2}{*}{$\begin{array}{l}\text { Age and } \\
\text { sex }\end{array}$} & \multirow[t]{2}{*}{ Site } & \multirow[t]{2}{*}{ Histological diagnosis } & \multicolumn{3}{|c|}{ Markers } & \multirow[t]{2}{*}{ Final diagnosis } \\
\hline & & & $C L A$ & Mur & $a T$ & \\
\hline \multicolumn{7}{|c|}{ PD7/26 Negative lymphomas } \\
\hline $58 \mathrm{~F}$ & Retroperitoneal & Anaplastic tumour, large celled & Trace & $\operatorname{lom}^{*}$ & $1^{*}$ & Lymphoma, B cell? \\
\hline $45 \mathrm{M}$ & Small intestine & Lymphoma? & Trace & $3^{(1810+1)}$ & & Lymphoma, histiocytic \\
\hline $50 \mathrm{~F}$ & Small intestine & Lymphoma, histiocytic? & Trace & 2 & 2 & Lymphoma, histiocytic \\
\hline $23 \mathrm{M}$ & Axilla (brachial plexus) & Lymphoma, histiocytic? & & 1 & 3 & Lymphoma, histiocytic \\
\hline $88 \mathrm{~F}$ & Tonsil & Lymphoma, high grade? & $\mathbf{0}$ & 3 & 3 & Lymphoma, histiocytic \\
\hline \multicolumn{7}{|c|}{ Histiocytic tumours } \\
\hline $55 \mathbf{F}$ & Retroperitoneal & $\begin{array}{l}\text { Malignant fibrous histiocytoma? } \\
\text { Hodgkin's disease? }\end{array}$ & 1 & 1 & 1 & Lymphoma, histiocytic \\
\hline $62 \mathrm{~F}$ & Lip & CLL and lymphoma (Richter's syndrome) & 3 & 2 & 3 & Lymphoma, histiocytic \\
\hline $60 \mathrm{~F}$ & Breast & Anaplastic tumour & 1 & 2 & 1 & Lymphoma, histiocytic \\
\hline $45 \mathrm{M}$ & $\begin{array}{l}\text { Liver and multiple sites } \\
\text { (necropsy) }\end{array}$ & Malignant fibrous histiocytoma & 0 & 0 & 1 & Compatible with MFH \\
\hline $26 \mathrm{~F}$ & Bone (rib) & Malignant fibrous histiocytoma of bone & 3 & 2 & $\mathbf{0}$ & Compatible with MFH \\
\hline $39 \mathrm{~F}$ & Retroperitoneal (psoas region) & $\begin{array}{l}\text { Myxoid tumour: malignant fibrous } \\
\text { histiocytoma? Liposarcoma? }\end{array}$ & 1 & 3 & 2 & Compatible with MFH \\
\hline $23 \mathrm{~F}$ & Bone (cervical spine) & Giant cell tumour of bone? & 0 & 2 & 2 & $\begin{array}{l}\text { Compatible with giant } \\
\text { cell tumour }\end{array}$ \\
\hline
\end{tabular}

CLA = Common leucocyte antigen (PD7/26); Mur = muramidase; aT = alpha-1-antitrypsin.

*Histologically different cells stained with IgM and histiocytic markers.

MFH = malignant fibrous histiocytoma.

Seven cases of probable Hodgkin's disease were received, but all had histology that was atypical. In the three with recognisable Reed-Sternberg or Hodgkin cells these cells reacted with histiocytic markers. These included two in which frozen sections were positive with the macrophage marker FMC33. ${ }^{15}$ Previous studies have also suggested a myeloid nature for these cells. ${ }^{1718}$

OTHER TUMOURS GIVING NEGATIVE REACTIONS WITH PD7/26 AND CAM5.2

In a total of $25(28 \%)$ of the 88 tumours of uncertain type staining with CAM5.2 and PD7/26 was negative, and there was no other evidence of a lymphomatous or carcinomatous nature. In four of these extensive staining for $\mathrm{S} 100$ protein and a positive neurone specific enolase reaction indicated that they were melanomas. Two tumours that had provisional histological diagnoses of neuroblastoma and neurofibroma were also S100 positive.

A vimentin antibody that was capable of staining paraffin embedded sections became available towards the end of the study. The previously undiagnosed cases were tested, and five were positive (Fig. 7). These, together with three cases of malignant fibrous histiocytomas reactive with histiocytic markers and two angiosarcomas reactive with positive factor VIII staining, made a total of $10(11 \%)$ sarcomas that were identified.

COMPARISON OF HISTOLOGICAL AND IMMUNOHISTOCHEMICAL DIAGNOSES

There was histological uncertainty of the tissue of ori- gin with all the tumours of the principal group stud- $\vec{\bullet}$ ied. In these cases the initial most probable diagnosis was compared with that reached after the investigation (Table $2 b$ ). In some instances no initial opinion could be given as to the tissue of origin; in others no definite result was obtained by immunohistochemistry. The remainder were classed as concordant or discordant. Of these, most were concordant $(57 \%)$ but in 11 instances $(13 \%)$ immunohistochemistry suggested an unexpected di-

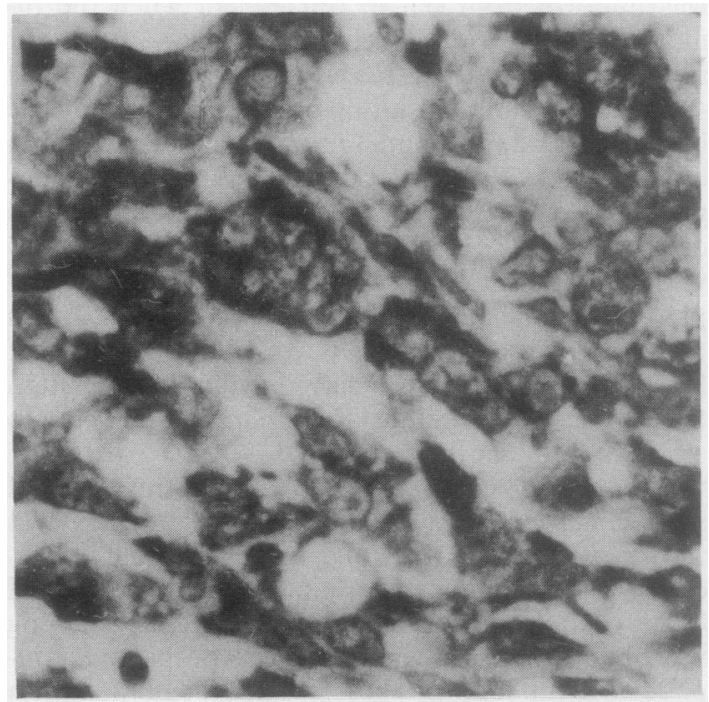

Fig. 7 Sarcoma of thyroid reacted with vimentin antibody. Most tumour cells show intense staining. 


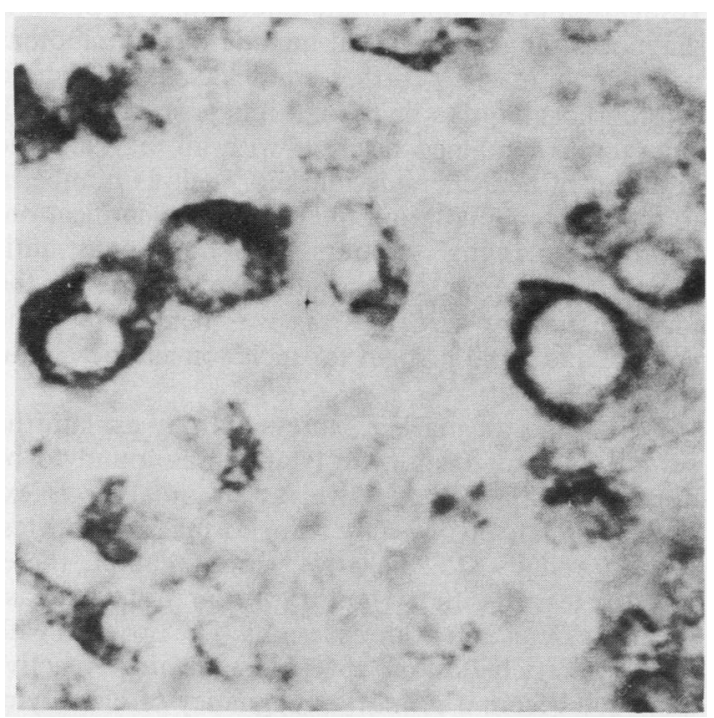

Fig. 8 Carcinoma of breast with provisional histological diagnosis of lymphoma. Large cells are stained with HMFG2. CAM5.2 staining was similar (case 3, Table 5).

agnosis. Table 5 summarises these cases. Eight proved to be carcinomas. Interestingly, three of these were breast lesions and had been initially diagnosed as lymphomas (Fig. 8).

Comparison of the initial with the final diagnoses showed that the only overall appreciable difference was that a greater proportion of carcinomas were found after immunohistochemical investigation.

\section{Discussion}

The ability to perform immunohistochemistry on formalin fixed paraffin embedded sections is of immense practical use. The technique, however, was limited by the finding that the antigenic structures on many useful marker proteins are destroyed or masked by the tissue processing. The extent of the antigenic loss varied greatly from one protein to another and may even differ between epitopes on the same protein. Some surface membrane antigens were irreversibly lost, but there were many cytoplasmic antigens that survive. Even these may be masked as a result of deleterious changes during tissue processing, and we found that treatment of the sections with enzymes to reverse this process was essential for reliable results with many monoclonal antibodies. ${ }^{11}$ Inappropriate enzymes used may damage the epitopes to be detected; an effect that can cause a decrease rather than an enhancement of staining, particularly at longer incubation times. The optimal enzymes (Table 1) permitted satisfactory results without the necessity for a range of digestion times with each case for diagnosis: this would have required an impractical number of sections.

If circumstances would allow a choice of tissue processing methods specifically designed to enhance antigen preservation should now reduce these problems greatly and permit the detection of membrane antigens in paraffin embedded sections. ${ }^{19} 20$ Their use, however, is likely to be possible only in specialist centres, and for the present it seems certain that many diagnostic problems will arise in formalin fixed material and be referred for immunohistochemistry.

Indirect immunoperoxidase is a suitable technique for routine investigations as it can easily be completed in a working day. It is not, however, as sensitive as other more complex techniques and may occasionally give rise to false negative results. Nevertheless, with proper application and choice of markers, diagnostic inaccuracy can be avoided. The immunogold-silver

Table 5 Cases in which immunohistochemistry gave an unexpected diagnosis

\begin{tabular}{|c|c|c|c|c|}
\hline \multicolumn{2}{|c|}{ Age and sex Site of lesion } & \multirow{2}{*}{$\begin{array}{l}\text { Histological diagnosis } \\
\text { Lymphoma }\end{array}$} & \multirow{2}{*}{$\begin{array}{l}\text { Immunohistochemical } \\
\text { diagnosis }\end{array}$} & \multirow{2}{*}{$\begin{array}{l}\text { Marker results } \\
\text { CAM5.2 + HMFG2 + + } \\
\text { PD7/26- }\end{array}$} \\
\hline $80 \mathrm{~F}$ & Breast & & & \\
\hline $31 \mathrm{~F}$ & Breast & Lymphoma & Carcinoma & $\begin{array}{l}\text { CAM5.2 + + HMFG2 + } \\
\text { PD7/26- }\end{array}$ \\
\hline $51 \mathrm{~F}$ & Breast & Lymphoma & Carcinoma & $\begin{array}{l}\text { CAM5.2 + + HMFG2 + + } \\
\text { PD7/26 - }\end{array}$ \\
\hline $74 M$ & Inguinal lymph node & Lymphoma & Carcinoma & $\begin{array}{l}\text { CAM5.2 + + HMFG2 + } \\
\text { PD7/26- }\end{array}$ \\
\hline $66 \mathrm{M}$ & Bone marrow & Lymphoma & Carcinoma prostate & PrAP ++ PSAg - CAM5.2 - \\
\hline $\begin{array}{l}41 \mathrm{M} \\
22 \mathrm{~F} \\
83 \mathrm{~F} \\
74 \mathrm{M} \\
69 \mathrm{M} \\
64 \mathrm{M} \\
? ?\end{array}$ & $\begin{array}{l}\text { Retroperitoneal lymph nodes } \\
\text { Liver } \\
\text { Thyroid } \\
\text { Stomach } \\
\text { Skin } \\
\text { Skin } \\
\text { Skin }\end{array}$ & $\begin{array}{l}\text { Lymphoma histiocytic } \\
\text { Lymphoma histiocytic?? } \\
\text { Ca. thyroid (spindle cell) } \\
\text { Ca. stomach } \\
\text { Melanoma } \\
\text { Sarcoma } \\
\text { Carcinoma/Melanoma? }\end{array}$ & $\begin{array}{l}\text { Carcinoma } \\
\text { Sarcoma } \\
\text { Sarcoma? Melanoma?? } \\
\text { Melanoma } \\
\text { Carcinoid } \\
\text { Carcinoma } \\
\text { Granulation tissue }\end{array}$ & $\begin{array}{l}\text { *CAM5.2 + } \\
\text { CEA + + Vimentin + } \\
\text { S100+ NSE + Vimentin + + + } \\
\text { S100+ + + NSE - CAM5.2 - } \\
\text { S100+ + CAM5.2 + } \\
\text { CAM5.2 + + + } \\
\text { Vimentin + CAM5.2 - }\end{array}$ \\
\hline
\end{tabular}

*Positive in frozen section only, negative in paraffin. 
technique ${ }^{21}$ offers much greater sensitivity, so that surface immunoglobulin can be detected on lymphocytes in paraffin sections, but it takes longer to perform and may not be very suitable for routine application.

The ability of the combination of the cytokeratin antibody CAM5.2 and the common leucocyte antigen PD7/26 to identify accurately nearly $90 \%$ of the carcinomas and lymphomas among a collection of tumours of unknown type means that screening with these antibodies is a useful initial stage in their diagnosis by immunohistochemistry.

The second cytokeratin antibody used, LP34, proved to be a complementary reagent to CAM5.2. It filled an important gap in the spectrum of reactivity of CAM5.2, the weak, or even negative reaction with squamous epithelia and their tumours. Mesotheliomas also express some cytokeratins similar to those in squamous epithelia ${ }^{22}$ : the presence of strong LP34 and CAM5.2 staining combined with a negative CEA reaction may be of considerable diagnostic use with these tumours. More extensive studies are required to assess the exact specificity of this pattern.

Apart from the prostatic markers, the panel provided only limited evidence of the organ of origin of carcinomas. Many more organ specific markers are required before a good success rate can be achieved in assigning carcinomas to an organ. Promising antibodies specific for lung, breast, and ovarian carcinomas have recently been produced. ${ }^{23}$

As for the lymphomas, PD7/26 positive lesions can be confidently placed in this group. Their further analysis was hampered by the lack of specific B and T lymphocyte surface markers that survive routine fixation to an extent that permits staining by immunoperoxidase.

The detection in several cases of monotypic expression of IgM on malignant cells without detectable light chain evidence of monoclonality deserves comment. Although B cell lymphomas may occasionally fail to express light chains, the more likely explanation of this finding is that the light chain determinants of immunoglobulins are considerably more difficult to detect than IgM, due principally to higher background staining. Care has to be taken, however, in the diagnosis of a B lymphocyte origin of a lymphoma on the basis of heavy chain immunoglobulin staining alone, as macrophages may take up large quantities of immunoglobulins and give strong staining. This is often composed of several heavy chain classes, and may therefore be distinguished. ${ }^{25}$ Despite these difficulties some useful, though not always conclusive, evidence of malignant cell type was obtainable in two thirds of non-Hodgkin's lymphomas.

The small proportion of cases remaining that are negative with both screening antibodies then have to be tested with a somewhat wider range of markers, but normally the morphology will point the in- vestigation in an appropriate direction. The possible diagnoses range widely and include rare carcinomas and lymphomas, so further epithelial and lymphoid cell markers have to be used. Some probable oat cell carcinomas remained negative with all markers: the addition of neuropeptide markers such as bombesin to the panel might permit their positive identification. Of the remaining tumours, the polyclonal antivimentin antiserum was an effective reagent for the identification of sarcomas, as was neurone specific enolase and $\mathrm{S} 100$ protein for melanomas and neural tumours.

Low values of marker expression may explain the several cases of histiocytic lymphomas found to be apparently PD7/26 negative, as this marker is expressed relatively weakly on normal histiocytes. PD7/26 and CAM5.2 negative tumours should, therefore, be tested with $\alpha-1$-antitrypsin and muramidase to ensure detection of these lesions. The problem with histiocyte rich lesions of distinguishing reactive histiocytes from a primary malignancy of histiocytes still, however, remains. Although doubt has been cast by gene rearrangement studies on the specificity of the histiocytic markers, ${ }^{26}$ the occurrence of typically histiocytic features such as phagocytosis in some tumours is evidence that these tumours, at least, must have a true histiocytic nature. The range of tumours seen in this study suggests that there is a spectrum of histiocytic malignancies ranging from lymphomas to malignant fibrous histiocytosis and giant cell tumours of bone.

The number of times that anaplastic tumours are diagnosed as carcinoma seems to be slightly higher than those occasions when they are diagnosed as lymphoma, while other tumour types or undiagnosable lesions form about a third of the total. This distribu- ? tion differs slightly from that found by Gatter et al, ${ }^{2}$ who found that most tumours of uncertain tissue of origin were diagnosed as lymphomas. This apparent difference is probably of little importance, as the material is selected by the interests of the hospital concerned and by the decision of the pathologist to refer it for immunohistochemistry.

This study has shown that immunohistochemistry has an important role in the diagnosis of anaplastic tumours that cannot be ascribed a definite tissue of origin by conventional histology. Screening such $\omega$ specimens with CAM5.2 and PD7/26 is a straightforward initial step that can be adopted by many his- 0 topathology laboratories; these reagents are now commercially available (Laboratory Impex, Twicken- ? ham, or Becton-Dickinson and Dako, High T Wycombe). The technique is highly complementary to conventional histology: we found it very successful even in tumours that were otherwise entirely un- $\mathbb{Q}$ diagnosable. The differences in optimum treatment $\overline{0}$ regimens for various tumours mean that accurate diagnosis will be of considerable benefit to the patient. 
We thank Drs GAK Missen, B Hartley, Isobel Filipe, Rosemary Millis, and Calypso Barbatis for referring cases for investigation, and Mrs Elizabeth Abdulla for help with the earlier part of the study. Monoclonal antibodies were generously provided by Dr David Mason and Ms Jackie Cordell; the John Radcliffe Hospital, Oxford; and Miss Carol Makin FRCS, Drs Birgitte Lane, Joyce Taylor-Papadimitriou, and Ms Cynthia Dixon; Imperial Cancer Research Fund Laboratory, Lincoln's Inn, London. The work was funded by grants from the locally organised research scheme of the South East Thames region of the $\mathrm{Na}$ tional Health Service.

\section{Addendum}

Since this work was done, the following useful monoclonal antibodies have become available for the staining of paraffin sections. Leu Mi (Becton Dickenson) for Hodgkin's disease and myeloid cells; MT1 (Eurodiagnostics) for $\mathrm{T}$ lymphocytes and myeloid cells; MB1 (Eurodiagnostics) for B lymphocytes.

\section{References}

${ }^{1}$ Gatter KC, Alcock C, Heryet A, et al. The differential diagnosis of routinely processed anaplastic tumours using monoclonal antibodies. Am J Clin Pathol 1984;82:33-4.

${ }^{2}$ Gatter KC, Alcock C, Heryet A, Mason DY. Clinical importance of analysing malignant tumours of uncertain origin with immunohistological techniques. Lancet 1985 ; :1302-5.

${ }^{3}$ Lauder I, Holland D, Mason DY, Gowland G, Cunliffe WJ. Identification of large cell undifferentiated tumours in lymph nodes using leucocyte common and keratin antibodies. Histopathology 1984;8:259-72.

4Makin CA, Bobrow LG, Bodmer WF. Monoclonal antibody to cytokeratin for use in routine histopathology. J Clin Pathol 1984;37:975.

s Osborn M. Intermediate filaments as histologic markers. An overview. J Invest Dermatol 1983;81:104-7.

${ }^{6}$ Moll R, Franke WW, Schiller DL, Geiger B, Kupler R. The catalog of human cytokeratins: patterns of expression in normal epithelia, tumours and cultured cells. Cell 1982;31:11-24.

7 Epenetos AA, Bobrow LG, Adams TE, Collins CM, Isaacson PG, Bodmer WF. A monoclonal antibody that detects HLA-D region antigen in routinely fixed wax embedded sections of normal and neoplastic lymphoid tissues. J Clin Pathol 1985;38:12-7.

${ }^{8}$ Arklie J, Taylor-Papadimitriou J, Bodmer WF, Egan M, Millis R. Differentiation antigens expressed by epithelial cells in the lactating breast are also detectable in breast cancer. Cancer 1981;28:23-9.

${ }^{9}$ Gatter KC, Abdulaziz Z, Beverley P, et al. Use of monoclonal antibodies for the histological diagnosis of human malignancy. $J$ Clin Pathol 1982;35:1253-67.

${ }^{10}$ Warnke RA, Gatter KC, Falini B, et al. Diagnosis of human lymphoma with monoclonal anti-leucocyte antibodies. New Engl $J$ Med 1983;309:1275-81.

11 Poston RN, Sidhu YS, Makin CA, Mason DY. Specific enzyme treatment is required for individual monoclonal antibodies in immunohistochemistry with formalin fixed sections. Protides of Biological Fluids 1985;32:557-60.

${ }^{12}$ Gerdes J, Naiem M, Mason DY, Stein H. Human complement (C3b) receptors defined by a mouse monoclonal antibody. Immunology 1982;45:645-43.

${ }^{13}$ Marshall RJ, Herbert A, Braye SG, Jones DB. Use of antibodies to CEA and HMFG to distinguish carcinoma, mesothelioma and reactive mesothelium. J Clin Pathol 1984;37:1215.

${ }^{14}$ Nap M, Ten Hoor K, Fleuren G-J. Cross-reactivity with normal antigens in commercial anti-CEA sera used for immunohistology. The need for tissue controls and absorptions. Am J Clin Pathol 1983;79:25-31.
${ }^{15}$ Brooks DA, Zola H, McNamara PJ, et al. Membrane antigens of human cells of the monocyte/macrophage lineage studied with monoclonal antibodies. Pathology 1983;15:45-52.

${ }^{16}$ Burmester GR, Winchester RJ, Dimitriu-Bona A, Klein M, Steiner G, Sissons HA. Delineation of four cell types comprising the giant cell tumour of bone. Expression of Ia and monocyte/macrophage lineage antigens. $J$ Clin Invest 1983;71:1633-48.

${ }^{17}$ Payne SV, Wright DH, Jones KJM, Judd MA. Macrophage origin of Reed-Sternberg cells: an immunohistochemical study. J Clin Pathol 1982;35:159-66.

${ }^{18}$ Stein H, Uchanska-Ziegler B, Gerdes T, et al. Hodgkin's and Sternberg-Reed cells contain antigens specific to late cells of granulopoiesis. Int J Cancer 1982;29:283.

${ }^{19}$ Tanaka H, Ishikawa E. Immunohistochemical demonstration of surface antigen of human lymphocytes with monoclonal antibody in acetone fixed paraffin embedded sections. $J$ Histochem Cytochem 1984;32:452.

${ }^{20}$ Collings LA, Poulter LW, Janossy G. The demonstration of cell surface antigens on $T$ cells, $B$ cells and accessory cells in paraffin-embedded human tissues. J Immunol Methods 1984;75:227-39.

${ }^{21}$ Holgate CS, Jackson P, Lauder I, Cowen PN, Bird CC. Surface membrane staining of immunoglobulins in paraffin sections of non-Hodgkin's lymphomas using immunogold-silver staining technique. J Clin Pathol 1983;36:742-6.

${ }^{22}$ Corson JM, Pinkus GS. Mesothelioma: profile of keratin proteins and carcinoembryonic antigen. Am J Pathol 1982;108:80-7.

${ }^{23}$ Wright GL. Monoclonal antibodies and cancer. New York: Marcel Dekker. 1984.

${ }^{24}$ Albores-Saavedra J, Nadji M, Civantos F, Morales AR. Thyroglobulin in carcinoma of the thyroid: an immunohistochemical study. Hum Pathol 1983;14:62-6.

${ }^{25}$ Isaacson P, Wright DH, Judd MA, Jones DB, Payne SV. The nature of the immunoglobulin containing cells in malignant lymphoma. J Histochem Cytochem 1980;28:761-70.

${ }^{26}$ Isaacson PG, O'Connor NTJ, Spencer JO, et al. Malignant histiocytosis of the intestine: A T cell lymphoma. Lancet 1985;ii:688-91.

${ }^{27}$ Springall DR, Gu J, Cocchia D, et al. The value of S100 immunostaining as a diagnostic tool in human malignant melanomas. A comparative study using $\mathrm{S} 100$ and neuron-specific enolase antibodies. Virchow Arch (A) 1983;400:331-43.

${ }^{28}$ Watanabe S, Nakajima T, Shimosato Y, et al. Malignant histiocytosis and Letterer-Siwe disease. Neoplasms of T-zone histiocyte with S100 protein. Cancer 1983;51:1412-24.

${ }^{29}$ Sheppard MN, Corrin B, Bennett MH, Marangos PJ, Bloom SR, Polak JM. Immunocytochemical localization of neurone specific enolase in small cell carcinomas and carcinoid tumours of the lung. Histopathology 1984;8:171-81.

${ }^{30}$ Mason DY, Bell JI, Christensson B, Biberfield P. An immunohistological study of human lymphoma. Clin Exp Immunol 1980;40:235-48.

${ }^{31}$ Mason DY, Taylor CR. The distribution of muramidase (lysozyme) in human tissues. J Clin Pathol 1975;28:124-32.

32 Isaacson P, Wright DH, Jones DB. Malignant lymphoma of true histocytic (monocyte/macrophage) origin. Cancer 1983;51:80-91.

${ }^{33}$ Palmer PE, Wolfe H. Immunocytochemical localization of oncodevelopmental proteins in human germ cell and hepatic tumours. J Histochem Cytochem 1978;26:523-31.

${ }^{34}$ Palmer PE, Satii H, Wolfe HJ. Alpha-1 antitrypsin and alphafetoprotein markers in endodermal sinus tumours. Am $\mathrm{J}$ Clin Pathol 1976;65:576.

${ }^{35}$ Nadji M, Tabei SZ, Castro A, et al. Prostatic specific antigen: an immunohistologic marker for prostatic neoplasms. Cancer 1981;48:1229-32.

${ }^{36}$ Lloyd RV, Sisson JC, Marangos PJ. Calcitonin, CEA and neuron specific encolase in medullary thyroid carcinoma. Cancer 1983;51:2234-9.

Requests for reprints to: Dr RN Poston, Department of Histopathology, Medical School, Guy's Hospital, London Bridge, SE1 9RT. 